Journal of Social Sciences (COES\&RJ-JSS)

ISSN (E): 2305-9249 ISSN (P): 2305-9494

Publisher: Centre of Excellence for Scientific \& Research Journalism, COES\&RJ LLC

Online Publication Date: $1^{\text {st }}$ April 2018

Online Issue: Volume 7, Number 2, April 2018

https://doi.org/10.25255/jss.2018.7.2.74.85

\title{
Indigenous Identity and Hybridity in the Indian Context \\ As \\ Portrayed in Arundhati Roy's The God of Small Things
}

\author{
Halimah Mohamed Ali \\ halimah@usm.my
}

\begin{abstract}
:
Arundhati Roy's novel The God of Small Things (GOST) (1996), has been described by Salman Rushdie as a novel that has been written artistically and well. It is a very ambitious novel. The style is quite personal although sometimes we see glimpses of the Rushdian style in her writing. Making use of her ambition and personal style Roy tackles indigenous issues and hybridity effortlessly. Through these two subjects we are introduced to themes of identity, human relationship, culture and politics. All these will be analysed using the hybridity theory and indigenous theory. This paper explores how Roy presents indigenous issues and hybridity in GOST in relation to the themes mentioned. The narrative poses questions about these issues which are difficult to answer. It also gives contradicting views about hybridity. Roy does not give us an answer as to whether we should accept hybridity or reject it. GOST can also be read as a postmodernist novel because of its treatment of time and space and its projection of place in an effort to juxtapose locality with identity. Nevertheless, Roy 's work is not an effort of imposing an identity on the Indian public, neither is it a project to define the Indian identity. This paper argues that GOST negotiates, questions and experiments with identity via symbols that represent identity: language, culture, politics and human relationship. Roy is very perceptive in presenting her narrative, however she reserves her judgment, and leaves us to make our own conclusions.
\end{abstract}

Key words:

Arundhati Roy, Rushdie, indigenous, hybridity, identity

Citation:

Ali, Halimah Mohamed; (2018). Indigenous Identity and Hybridity in the Indian Context As Portrayed in Arundhati Roy's The God of Small Things; Journal of Social Sciences (COES\&RJ-JSS), Vol.7, No.2, pp:74-85; https://doi.org/10.25255/jss.2018.7.2.74.85. 


\section{INTRODUCTION}

The art of the novel that was introduced by the Western world has flourished in Asia. The novel is a recently acquired tool of expression in Asia because Asian literature is based upon oral literary tradition. In India, significant contribution to the novel in English started in the 1930's by writers like R.K. Narayan, Mulk Raj Anand, Raja Rao and many more (Walsh, 1978, 63-72). Indian writing in English has evolved since the 1930's. From being an unknown corpus, and celebrated only in "niche literary circles", it has gained worldwide attention. It started with Salman Rushdie who won the prestigious Booker Prize in 1981 for this novel Midnight's Children. Rushdie put Indian writing on the world map, and ever since then it has prospered. According to Rushdie new (Indian) writers "emerge every few weeks"( Rushdie, 1997, x). One of the writers that emerged is Arundhati Roy an Indian citizen and a trained architect turned novelist. She created history when she obtained a one million-dollar contract for her first novel The God of Small Things (GOST) that later won the Booker Prize in 1997. Her success has brought a great deal of attention to Indian writing in English, and now agents and publishers in Britain are "looking for the next Roy" (Tejpal, 1999).

There have been other scholars that have written on Roy's GOST. A.N. Dwivedi's edited book titled Arundhati Roy's Fictional world (A Collection of Critical Essays) (2001) is a collection 12 essays on GOST. The issues that these essays deal with range from communism that is presented in the book, the popularity of the book, the reason it become an award winning novel. The theme, language and style of writing is also analysed in one of the essays in the book, human psyche is another subject of anlaysis, feminism and law, the interpretation of the title, languag and socio-politics.

Another work that has been produced to discuss Roy's novel is Arundhati Roy: The Novelist Extraordinary edited R.K. Dhawan (1999). It consists of 44 essays including the introduction. The introduction is by R.K. Dhawan himself and he postulates the idea that Arundhati Roy is an extraordinary novelist. This book is divided into 11 sections. The first is the introduction. The second is titled The Role of the Media where two essays tackle the issues of how GOST was written,is being marketed and how the media has responded to it. The second essay by Madhusudhan Mukherjee discusses why GOST sells. The third section is on the question of the woman. There are five essays that look into the power politics of women, feminist aspects as well as the man-woman relationship. The fourth section is title The Forbidden Relationship. There are seven essays that discuss the forbidden relationships in the novel. There are two forbidden relationships; one between Velutha and Ammu and the incestuous relationship of Rahel and Estha. The fifth section Exploring the Past and the Present also has seven essays in it. The first essay in this section is titled Arundhati Roy's and Salman Rushdie's Postmodern India by Victor Ramraj. It is a comparative study of the two Booker Prize winners, the 'father' and the 'child', who both hail from India. This section deals with Indian-English literature as GOST is part of that canon and discusses the future of the literature. It also looksat the eccentricities that are present in the novel. The sixth section title the Big and Small concentrates on the title of the book. It also discusses liminality as a concept of creating another identity or the third space that has been introduced by Homi K. Bhabha through his theory Nation and Narration. The seventh section is about the variety in the themes 
that are present in the novel. There are five essays in this section and they discuss the feelings of the children, thematic symbolism, how art and life is projected in GOST, the manifestation of anger in the novel and the beauty of the novel. The beauty of the fiction is clearly seen in the title of this essay The God of Small Things: A Rainbow in the Sky by Pradeep Trikha. The eighth section concentrates on the setting. It consists of only two essays. The ninth section in titled The Architectonics. It has six essays. This section looks at the "architecture" of the novel. We have to keep in mind that Roy was trained as an architect before she became an author. Thus the "architecture" of her novel exudes beauty and intricacies that cannot be found in many writers of her time. The tenth section discusses the language and the eleventh section postulates that Roy and her novel are both emissaries of peace.

Another work on Roy that has been written and published in Malaysia is Orientalism From Within: Arundhati Roy and Her Contemporaries by Halimah Mohamed Ali (2011). This book introduces the concept of catering and pandering to the West by IndianEnglish writers. Her arguments are supported by her theory Orientalism From Within that she uses to read the three texts selected for her book. One of the texts is GOST. She argues that the Indian-English writers including Roy produces Orientalism From Within and sells their works to the West. Orientalism From Within is a theory that discusses how native Indian writers reproduce Western style Orientalism for the Western public. The reason why they reproduce Orientalism is due to the fact that they yearn for fame and fortune since Orientalism is an exotic entity and is marketable. It is also produced by native Indian writers because the West does not want to be seen as politically incorrect. The pictures of the down trodden Other coming from the Other himself/herself would be more authentic and absolve the West from being labelled as politically incorrect. However, this project of the West exploits the Other and has created Orientalism from within the natives' minds and states.

GOST, has been described by Rushdie as a novel that that is "full of ambition and sparkle and written in a highly wrought and utterly personal style (1997, xxii). Making use of her ambition and personal style Roy tackles indigenous issues and hybridity effortlessly. Through these two subjects we are introduced to themes of identity, human relationship, culture and politics. The project of this paper is different from the others that have been discussed above. It aims to explore how Roy presents indigenous issues and hybridity in GOST in relation to the themes mentioned above.

\section{SYNOPSIS}

Roy's booker-Prize-winner is set in Ayemenem a small town in the state of Kerala in India. GOST revolves around the childhood memories of a pair of twins Rahel and Estha, who undergo a drastic change when their 9-year-old cousin Sophie Mol, who comes visiting from England drowns in the river. The story begins in the month of June, when Rahel and Estha have both reached the age of thirty-one. Narrated by an omniscient narrator the plot does not move in a sequence. The narration jumps from the present to the past and vice versa. Sometime past and present are fused together, and the reader has to be very careful in absorbing in the details so as to avoid confusion. The novel can be seen as if it is encased in a frame of time, but a frame of different time zones. It 
begins with the present, with Rahel and ends in the past, where Ammu, Rahel's mother says goodbye to her untouchable lover, Velutha.

\section{THEORETICAL FRAME WORK: HYBRIDITY AND INDIGENEITY}

Hybridity that is prevalent in the novel is not a new concept, though it is a term that is widely used by recent colonial and postcolonial theories like Gayatri Chakravorty Spivak and Homi K. Bhabha. It has been in use for many centuries to describe plants and animals, but it was only applied to humans in the 19 century. A hybrid is technically viewed as a cross between two different species. The term hybridization is a reminder of the Victorian's vocabulary who looked upon different races as different species. Young defines hybridity as:

At its simplest, hybridity...implies a disruption and forcing together of any unlike living things... Hybridity is a making one of two different things so that it becomes impossible for the eye to detect the hybridity of a geranium or a rose (Young 1995: 26).

Hybridity is not always as uncomplicated as described by Young. This description is only of physical hybridity. The issues that will be discussed in this paper do not concern physical and racial hybridity alone, but also cultural hybridity. It concerns the hybridity that is advocated by Homi K. Bhabha: the hybridity of cultural differences and the introduction of the third space. Nevertheless, racial hybridity cannot be ignored totally in this paper because of the fact that, "Culture and race developed together, imbricated within each other..." (Young, 1995, 28), and Roy presents both categories in her fiction.

Indigenization is a term used to in refer to the process that has turned something or someone into the native of the land. According to Sinha, “...indigenization would imply the way in which an element is so transformed as to make it nature or suited to the region, to the soil or the special features of the environment...or the sociocultural setting" (1993: 34). The phase where the "indigenization of psychology in India can be characterized as one of questioning, doubt, and a search for new identity" was visible in the mid 1960's and the 1970's (Sinha, 1993: 33). The process of indigenization was clearly evident during this phase and this was clearly shown by the "urge to develop a psychology rooted in India soil" (Sinha, 1993: 34). Sinha also argues that the indigenized subject is not the finished product, but the one that is going through the process of indigenization. According to him, "...indigenization is visible in the shaping of a process rather than in a finished product" (Sinha, 1993: 34).

Indigenous communities need to be defined. According to Jose R. Martinez Cobo, Indigenous communities, peoples and nations are those which, having a historical continuity with pre-invasion and pre-colonial societies that developed on their territories, consider themselves distinct from other sectors of the societies now prevailing on those territories, or parts of them. They form at present non-dominant sectors of society and are determined to preserve, develop and transmit to future generations their ancestral territories, and their ethnic identity, as the basis of their continued existence as peoples, in accordance with their own cultural patterns, social institutions and legal system (http://indigenouspeoples.nl/indigenouspeoples/definition-indigenous). 
Thus, if we take into consideration Sinha's theory of indigenization and Cobo's definition of indigenous communities the indigenized people are those that practice the culture of the land and whose children inherit it from them.

\section{THE ANALYSIS: HYBIDITY}

In GOST, Roy experiments with different types of hybridity. Her writing is an experimentation with identity formation because she presents hybridity vis-à-vis the form of language, race, religion, politics and culture. Hybridity is evident in the language that Roy uses. Much of Roy's experiment with language is done through the two main characters $\neg---$ the twins, Estha and Rahel. The narrative places them in a Malayalam speaking society, but the children's education is geared towards turning them into hybrids. They are reading Shakespeare and Kipling by age six, and they are trained to speak in perfect English by their family:

That whole week Baby Kochamma eavesdropped relentlessly on the twins private conversations, and whenever she caught them speaking in Malayalam, she levied a small fine which was deducted at source. From their pocket money. English, I will always speak in English. A hundred time each (36).

The twins are trained to use English correctly and in its pure form, without code switching or code mixing. Nevertheless they manage to hybridise the language by creating their own from of English. One example is of the twins reading backwards:

The red sign on the red and white arm said STOP in white. Rahel said. A yellow hoarding said BE INDIAN in red. 'NAIDI YUB, NAIDINI EB,' Estha said (59).

There are many instances in the novel where Roy plays with language and breaks language rules. As an example, the word nevertheless, becomes: 'Never. The. Less' (55). Most of her experiments with language is done by way of the twins as they read backwards and speak backwards and coin words together to form new words. Roy creates for them their own world where adults are not allowed entrance.

Roy's English is not The Queen's English. She writes in Indian-English, thus, she gives the language her literary voice and her distinctive style, because she is Indian. Her experimentation with language can also be read as her experimentation with identity the Indian identity. In the novel, language is a means that is used to form identities and she negotiates with it. Roy utilises language to present the idea of the individual identity: that distinctive style of language can exist as an individual identity can as well. It can be deduced that she does not want to restrict language to a compartment or a society; she wants to liberate her language from its archaic rules.

The author's creation of a distinctive and hybrid language in her narration gives the impression that she is comfortable with hybridity and advocates it. It is not only suggested by her use of language but also through the narrative voice. The narrator informs us that:

...Chacko said that Estha and Rahel were indecently healthy. And so was Sophie Mol. He said it was because they didn't suffer from inbreeding like most Syrian Christians. And the Parsees (16). 
The statement points out that interracial and inter-caste marriages are good and should be allowed or supported. Yet, apart from her language and this single statement for hybridity, Roy's narrative on this subject is laced with ambivalence. Many contradictions stand against Roy's supportive voice in the narrative. This will be further elucidated in the next paragraph.

The conflict resides in another type of hybridity that Roy presents - cultural hybridity. Their late grandfather, Pappachi, is described to be an Anglophile, "Chacko said that the correct word for people Like Pappachi was Anglophile... Chacko said that... Pappachi's mind had been brought into a state which made him like the English" (p.52). Roy has created a Syrian Christian family that does not have a concrete identity. The narrative provides us with details that suggest this:

Chacko told the twins that though he hated to admit it they were all Anglophiles. They were a family of Anglophiles. Pointed at the wrong direction, trapped outside their own history, and unable to retrace their steps because their footprints had been swept away (p.52).

The narrative points out that if one chose to be a hybrid then one had to forsake one' $s$ history and past. It stresses this through Chacko as he says, "...But we can't go in... because we've been locked out... We belong nowhere..." (53). Unlike Bhabha who supports the idea of a "transnational culture" Roy questions it. GOST can be used to test Bhabha's concept of hybridity. Bhabha argues, "The 'other' is never outside or beyond us; it emerges forcefully, within cultural discourse, when we think we speak most intimately and indigenously "between ourselves" (Bhabha 1990: 4). Roy points out through her fiction the consequences of allowing the Other to merge within one's cultural discourse. Like Franz Fanon's native intellectual which he describes in his book The Wretched of the Earth (1966), Roy's hybrid does not belong with the white man, neither can she/he go back to his/her own people and culture .

Apart from cultural hybridity, Roy also introduces racial hybridity. The children in the novel are presented as racial hybrids. Rahel and Estha are hybrids from a marriage between a Syrian Christian (their mother) and a Bengali-Hindu (their father). Their cousin Sophie Mol is a hybrid offspring of an English mother and a Syrian Christian father.

Roy raises doubts about racial hybridity through her narrative. Her reservations against it are clearly portrayed in the manner that she presents her hybrid characters. She does not allow the twins to lead a happy life and the people around them are portrayed to dislike them for it:

Baby Kochamma disliked the twins, for she considered them doomed, fatherless waifs. Worse still, they were Half-Hindu-Hybrids whom no self-respecting Syrian-Christian would ever marry (45).

Through Baby Kochamma's words, the narrative depicts that Hindu-Hybrids are not accepted by the Syrian-Christian society. It is not difficult to imagine that the Hindu 
society too would be uncomfortable with Syrian-Christian hybrids, though their point of view is not presented in the novel.

Roy's lack of confidence in racial hybridity is emphasized in her writing off of Sophie Mol's character. The death of Sophie Mol is a hint to the readers to consider the prospect that racial hybridity cannot be successful. Roy's discomfort with racial hybridity can be read similarly to Ashis Nandi's reading of Kipling: "Kipling's dilemma can be stated simply: he could not be both Western and Indian, he could be either Western or Indian" $(1993,2)$. Nandy goes on to argue that for an Indian, this would not have been a problem. He would have acknowledged this double identity and reconciled with the fact $(1993,72)$. However, it seems this is not the case that Roy puts forward. Roy's dilemma is analogous to Kipling's though the characters that she portrays are Indians or part Indian. The narrative puts forward the argument that it does not matter whether a hybrid personality is Western or Indian. She/he will face a dilemma of identity no matter what she/he is.

\section{THE ANALYSIS: INDIGENOUS IDENTITY}

In the above section hybridity has been dicussed in detila with connection to GOST. In the context of GOST hybridity cannot be discussed without considering indigenous issues, because both matters are intertwined in the novel. According to the Oxford English Dictionary the word indigenous is applicable to flora and fauna and means "produced naturally in a region; belonging natural to the soil". This definition can be connected to the earlier definition of hybridity. Indigenous is also defined as " belonging naturally to a place; native".

It is clear that Roy questions identity and negotiates with it. Thus, in her negotiations she takes her writing a step further. She does not only hybridizes her language but also tries to indigenize her narrative. According to Sinha, "...indigenization would imply the way in which an element is so transformed as to make it nature or suited to the region, to the soil or the special features of the environment...or the sociocultural setting" (1993: 34). It is clear that the form and the language that Roy uses to write in are foreign. So in order to make it local she intertwines English with Malayalam words. The indigenous element of the language is presented in the names that she uses. For example: "Mammachi" for grandmother, "Pappachi" for grandfather and "Ammu" for mother. Words like "Aiyyo Kashtam" (p.177) and "Sundarikutty" (p. 179) are only a few examples of Malayalam words that exist in the text. This style that Roy employs reveals that the text was not written with only foreign readers in mind although in her book Orientalism From Within: Arundhati Roy and Her Contemporaries, Halimah Mohamed Ali (2011), argues that Roy's project is to cater and pander to the West. Nevertheless, Mohamed Ali's arguments can be taken further to support the idea that Roy might be pandering and catering to her Western audience via the local language that she uses since it may enhance the idea of the exotic Other.

The setting of the novel too contributes to its indigenous characteristics. The action is set in Ayemenem, a town in the state of Kerala in India. The novel can be read as a self- 
expressive work because of the indigenous elements and its form as a quasiautobiography.

The text is also given an indigenous feature by the presentation of the caste system. Scholars like Harold A. Gould (1987) and Oliver Cromwell Cox (1948) have viewed the caste system as being traditionally Hindu. The caste system was brought to India by the Aryan in about $150 \mathrm{BC}$. It has survived time and is still practiced in modern India in the form that is almost as intact as it was first introduced. Untouchability, one of the themes that Roy portrays, is a branch of the caste system. Untouchables are those who do not fall into the four castes in Hinduism: Brahmins, Kshatriyas, Vaisyas and Sudras. Untouchability is still being practiced in India though political intervention has outlawed it. In the 1950 Indian Constitution, India was proclaimed to be a secular and democratic state. Equal opportunity and status were promised to all citizens. Discrimination based on caste, religion and gender was abolished by the Constitution. Special attention was given to the untouchables, tribals and backward classes. Nevertheless, discrimination based on caste has not been eliminated.

GOST is a critique of this ill that is evident in Indian society. It is ironic that in the novel those who discriminate on the basis of caste are people who ordinarily should be unbiased -- Syrian Christians and a Marxist leader. Roy's criticism is based on the argument that though laws have been formulated, and changes have been made, the core and the spirit of the Indian society's attitude towards untouchability has not changed. Her project is to challenge the caste system. In the novel she portrays a sexual relationship between an Untouchable man (Velutha) and a Syrian-Christian women (Ammu) that the Indian society considers to belong to the higher caste. Roy's move is very daring because even Mahatma Gandhi who fought for equal rights for the untouchables, and who declared himself to be an untouchable did not advocate close physical contact or relationship between untouchables and Indians of the higher caste:

Correspondents have asked whether inter-dining and inter-marriage are part of the movement against untouchability... I should never dream of making this reform, however desirable in itself it may be, part of an all-India reform which has been long overdue... It may even amount to a breach of faith with the masses to call upon them suddenly to view the removal of untouchability in a light different from what they have been thought to believe it to be (Green, 1987, 195).

It is clear that Gandhi was sensitive to the sentiments of his people. Though he wanted the untouchables to be treated on equal basis and more humanely he knew where to draw the line.

Compared to Gandhi, Roy is more adventurous in her quest to change the social norms of her society. Nevertheless, Roy does not carry through her project. The lovers' relationship in the narrative is not accorded a happy ending. Velutha dies in a police lockup a few days after their affair becomes publicly known, and years later Ammu dies alone in a rented room in Allepey, far away from her two children. It is as if Roy punishes the couple for their illicit inter-caste relationship. However, Roy should be viewed as an intelligent writer. Killing both lovers is her strategy of dissolving herself from criticism 
and the wrath of the Indian society, because the issue that she has tackled is very sensitive. Although she tries to be an agent of change, her writing merely suggests change in the Indian society's views concerning Untouchability, it does not strongly advocate reform.

Roy's caution is due to the fact that Untouchability has been ingrained in the Indian society for centuries. It is not only synonymous to Hinduism, but it is identical to India as well. It identifies the Indians and their country. That is why though the society that the narrative presents is a Christian society the caste system is still applicable to it. Even the Untouchable characters are Christians:

When the British came to Malabar, a number of Palavans, Palayas and Pulayas (among them Velutha's grandfather, Kelan) converted to Christianity and joined the Anglican Church to escape the scourge of Untouchability... It didn't take them long to realize that they had jumped from the frying pan into the fire. They were made to have separate churches, with separate services, and separate priests. As a special favour they were given their own separate Pariah Bishop (74).

The point that the narrative makes is that religions may change but the Indians' view of the Untouchables remain the same. Though Christianity is a religion that preaches equality among humans, in India it becomes a hybrid religion. It adopts the caste system as one of its unannounced doctrines. In the novel this case is very much pertinent to the Syrian Christians who believe that they are "descendants of one hundred Brahmins whom Saint Thomas the Apostle converted to Christianity when he travelled east after the Resurrection" (66). Roy's argument vis-à-vis her novel is that, to uphold the caste system, the Indian society will even take refuge in legends.

The caste system is utilized in GOST to criticize politics and politicians. The political system that Roy criticizes is Marxism. Her argument is that although Marxism is built upon the idea of equality for all, in India it is not able to stand up to the caste system, because politicians like K.N.M. Pillai have their own agenda. The Marxist leader who is a Brahmin is more conscious of his caste and political ambition than his duties toward his fellow member Velutha:

The only snag in Comrade K.N.M. Pillai's plans was Velutha. Of all the workers at Paradise Pickles, he was the only card-holding member of the Party, and that gave Comrade Pillai an ally he would have rather done without. He knew that all the other Touchable workers in the factory resented Velutha for ancient reasons of their own. Comrade Pillai stepped carefully round this wrinkle, waiting for a suitable opportunity to iron it out (121)

His ambition leads him to influence Chacko, Velutha's boss to dismiss him from the pickle factory:

The Paravan is going to cause trouble for you...Take it from me... get him a job somewhere else. Sent him off.. He may be very well okay as a person. But other workers are not happy with him. Already they are coming to me with complaints...You see, from local standpoint, these caste issues are very deep-rooted (278). 
Even when Velutha comes to Pillai for help after he is humiliated and threatened by Mammachi (Ammu's mother), Pillai turns him away by saying, "But Comrade, you should know that Party was not constituted to support workers' indiscipline in their private life" (28). Again an ideal system fails because of its selfish leader. The narrative points out the failure to us:

And there it was again. Another religion turned against itself. Another edifice constructed by the human mind, decimated by human nature (287).

An idea that in its principles holds all men as equal has no place in India. It is an ideal that shall never be upheld because of the caste system. The caste system did not perish in the name of religion - Christianity - that is supposed to embrace all men as equals, thus a notion as new as communism too does not have the power to change a culture that has been intact for centuries. The communism that can exist in India is only a hybrid communism, which makes allowances for the caste system. It does not exist on the basis of equality for all.

\section{CONCLUSION}

GOST is a novel that weaves the themes of identity, human relationship, culture and politics successfully within bigger subjects: hybridity and indigenous issues. The narrative poses questions about the system, which are difficult to answer. It also gives contradicting views about hybridity. Roy does provide a solution for us as to whether we should accept hybridity or reject it. GOST is a postcolonial novel that discusses the identity and locality of a hybrid postcolonial society that is indigenous to its environment. Nevertheless, Roy 's work is not an effort of imposing an identity on the Indian public neither is it a project to define the Indian identity. This is because India cannot be defined since it is culturally and linguistically fused as well as sundry. As it has been argued.

GOST negotiates, questions and experiments with identity via symbols that represent identity: language, culture, politics and human relationship. Roy presents her arguments skilfully, however, she reserves her judgment, and leaves her readers to make their conclusions.

\section{END NOTES}

More Information on this is available from an article written by Tarun J. Tejpal "The New Masters" at http://www.pathfinder.com/@@xY*Rushdie's AvgU A4SFOWIW7/asiaweek/97/0808/cs10.html and also Salman Rushdie's "Introduction" in The Vintage Book of Indian Writing 1947-1997 ed. by Salman Rushdie and Elizabeth West (London: Vintage, 1997) pp. ix-xxii.

Robert J.C. Young Colonial Desire: Hybridity in Theory, Culture and Race (London; New York: Routledge, 1995) p.26.

Many of Bhabha's view on hybridity are advocated in his writings such as in Nation and Narration (London: Routledge, 1990) and The Location of Culture (London: New York: Routledge, 1994). 
Homi K. Bhabha "Introduction: Narrating the Nation" in Nation and Narration ed. by Homi K. Bhabha (London; New York: R

Oxford Advanced Learner's Dictionary (fifth edition, 1995).

Harold A. Gould The Hindu Caste System: The Sacralization of a Social Order (Delhi: Chanakaya Publications, 1987) and Olive Cromwell Cox Caste, \& Race: A Study in social Dynamics (New York; London: Modern Reader Paperbacks 1948.

Harold A. Gould The Hindu Caste System: The Sacralization of a social order (Delhi: Chanakaya Publications, 1987) and Oliver Cromwell Cox Caste, Class, \& Race: A Study in social Dynamics (New York; London: Modern Reader Paperbacks, 1948)

Although Roy tried to avoid controversy, she was charged with obscenity charges by Sabu Thomas a lawyer in Kerala for depicting a sexual relationship between an untouchable man and a highcaste woman.

References

Architect of stories: a conversation with Arundhati Roy. Retrieved 21 August 1999 from http://www.amazon.com/exec/obidos/subst/f...ndhati-interview.html/002-45644450101446.

Bhabha, Homi K. (1990). Nation and Narration. London: Routledge.

Bhabha, Homi K. (1994). The Location of Culture. London; New York: Routledge.

Bhabha, Homi K. (1990). "Introduction: Narrating the Nation" in Homi K. Bhabha (ed.) Nation and Narration. London; New York: Routledge, 1990.

Cobo, Jose R. Martinez. Definition of indigenous peoples. Retrieved 4 July 2014 from http://indigenouspeoples.nl/indigenous-peoples/definition-indigenous.

Cox, Oliver Cromwell. (1948). Caste, \& Race: A Study in social Dynamics. New York; London: Modern Reader Paperbacks.

Dhawan. R. K. (ed.). (1999). Arundhati Roy: The Novelist Extraordinary. New Delhi: Prestige Books.

Dwivedi, A.N. (ed.). (2001). Arundhati Roy's Fictional Work (A Collection of Critical Essays). Delhi: B.R. Publishing Corporation.

Frantz Fanon. (1996). The Wretched of the Earth. New York: Grove Press Inc.

Gould, Harold A. (1987). The Hindu Caste System: The Sacralization of a Social Order Delhi: Chanakaya Publications.

Green, Martin. (1987). Gandhi in India: In His Own Words. Hanover: University Press of New England. 
Harvey, David. (1998). The Condition of Postmodernity. Oxford: Basil Blackwell.

Mohamed Ali, Halimah. (2011). Orientalism from Within: Arundhati Roy And Her Contemporaries. Pulau Pinang: Penerbit Universiti Sains Malaysia.

Nandy, Ashis. (1993). The Intimate Enemy: Loss and Recovery of Self Under Colonialism Delhi: Oxford University Press.

Oxford Advanced Learner's Dictionary (fifth edition, 1995).

Rushdie, Salman. (1997). "Introduction" in Salman Rushdie and Elizabeth West (eds.) The Vintage Book of Indian Writing 1947-1997. London: Vintage.

Sinha, Durganand. (1993). "Indigenization of Psychology in India dan its Relevance" in Uichol Kim and John W. Berry Indigenous Psychologies: Research and Experience in Culture Cultural Context. London: Sage Publications.

Tejpal, Tarun J. "The New Masters". Retrieved on 23 July 1999 from http://www.pathfinder.com/@@xy*Rushdie'sAvgU A4SFOWIW7/asiaweek/97/0808/cs10.html.

Tejpal, Tarun J. Tejpal “New Gold Rush in the East” in The Guardian 14 August 1999.

The Salon Interview "Winds, Rivers and Rain" Retrieved on 2 August 1999 from http://www.salonmagazine.com/sept97/00roy.html.

Venu Menon "Who's Ammu". Retrieved 2 August 1999 from http://wwrediff.com/news/oct/18booker.htm.

Venu Menon "Arundhati Roy". Retrieved 2 August 1999 from http://www.wish.unet.com/roy.tgost1.htm and from http://members.xoom.com/roy.tgost1.htm and from http://members.xoom.com/XOOM/feekarji.ar.htm.

Walsh, William Walsh. (1978). "The Indian Sensibility in English" in C.D. Narasimhaiah ed. Awakened Conscience: Studies in Commonwealth literature(Hong Kong; Singapore: Heinemann Education Books, 63-72.

"Who are the World's Indigenous Peoples?". Retrieved on 10 September 1999 from http://www.ciesin.org/docs/010-000a/Year_Worlds_Indig.html.

Young, Robert J.C. (1995). Colonial Desire: Hybridity in Theory, Culture and Race. London; New Y ork: Routledge. 